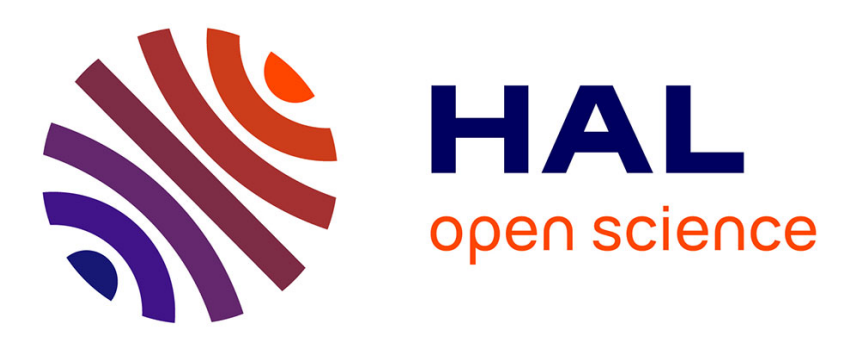

\title{
Global Emissions of Mineral Aerosol: Formulation and Validation using Satellite Imagery
}

\author{
Yves Balkanski, M Schulz, T. Claquin, C Moulin, P. Ginoux
}

\section{To cite this version:}

Yves Balkanski, M Schulz, T. Claquin, C Moulin, P. Ginoux. Global Emissions of Mineral Aerosol: Formulation and Validation using Satellite Imagery. Emissions of Atmospheric Trace Compounds, Eds Claire Granier, Paul Artaxo, Claire E. Reeves, Springer., 2004, 10.1007/978-1-4020-2167-1_6 . hal-02874022

\section{HAL Id: hal-02874022 \\ https://hal.science/hal-02874022}

Submitted on 18 Jun 2020

HAL is a multi-disciplinary open access archive for the deposit and dissemination of scientific research documents, whether they are published or not. The documents may come from teaching and research institutions in France or abroad, or from public or private research centers.
L'archive ouverte pluridisciplinaire HAL, est destinée au dépôt et à la diffusion de documents scientifiques de niveau recherche, publiés ou non, émanant des établissements d'enseignement et de recherche français ou étrangers, des laboratoires publics ou privés. 


\title{
Global Emissions of Mineral Aerosol: Formulation and Validation using Satellite Imagery
}

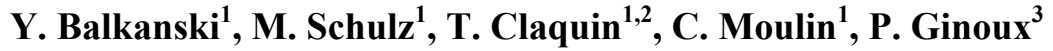 \\ ${ }^{1}$ Laboratoire des Sciences du Climat et de l'Environnement, 91190 Gif-sur-Yvette \\ Cedex, France \\ 2Now at Eurobios, 94234 Cachan Cedex, France \\ ${ }^{3}$ NASA GSFC, Greenbelt, MD-20771, United States.
}

\section{INTRODUCTION}

The most abundant aerosol components present in the atmosphere are dust and sea salt (Andreae 1995). Li et al. (1996) show that dust dominates the aerosol light-scattering over the tropical and sub-tropical Atlantic. Satellite retrievals also illustrate the importance of dust over large regions from arid deserts to remote oceanic regions downwind of West Africa, Asia and the Persian Gulf (Husar et al. 1997, Deuzé et al. 2000, Tanré et al. 2001). Furthermore, land modification, agricultural practices and the migration of desert fringes appear to have contributed to the increase in the dust transport over the Atlantic from the 1960s to the 1980s. These perturbations to the dust cycle brought by human activity are thought to account for 15 to $50 \%$ of the atmospheric dust load (Tegen and Fung 1995; Tegen, personnal communication, 2002).

Martin and Gordon (1988) and Falkowski et al. (1998) studied the limitation of oceanic primary production by iron-containing dust in areas of high nitrate-low chlorophyll regimes. The surface of dust also acts as a chemical reactor for key atmospheric gases that can be either adsorbed or oxidized. The species that have been examined so far to evaluate these heterogeneous pathways include $\mathrm{HNO}_{3}, \mathrm{~N}_{2} \mathrm{O}_{5}, \mathrm{SO}_{2}$ and $\mathrm{O}_{3}$ (Dentener et al. 1996 and 
references therein, Song et al. 2001). Ongoing laboratory, field and modeling studies show that $\mathrm{O}_{3}$ and $\mathrm{HNO}_{3}$ tropical and subtropical concentrations could be decreased by more than $10 \%$.

Last but not least, dust may pose a public health threat since it may cause respiratory disease, e.g. development of silicosis (Patial 1999), and by transporting spores of bacteria over long distance (Griffin et al. 2001).

The renewed interest in the atmospheric transport of mineral dust has been triggered by studies of how the direct (Tegen et al. 1997, Haywood and Boucher 2000, Harrison et al. 2001) and indirect effect of aerosols influence the Earth's radiative budget (Levin et al. 1996, Rosenfeld 2000). Unfortunately, there is a large uncertainty in the annual flux of desert dust to the atmosphere, which is estimated to range from 128 to $5000 \mathrm{Mt} \mathrm{yr}^{-1}$ (Pye 1987). The difficulties in modeling the atmospheric injection of mineral particles comes from the episodic nature of these events, which are controlled by local soil properties and atmospheric conditions.

Dust weathering and geological processes that produce small particles which can be transported over large distances determine the actual dust source areas (Prospero et al. 2002). Information from recent satellite studies is now used to identify the regions where dust is uplifted.

This paper has four parts: The first part describes the theory of dust generating schemes used in global models. The second part describes a global dust source scheme that is formulated on the basis of soil properties and satellite retrievals from TOMS (Total Ozone Mapping Spectrometer). The third part describes the regions where dust is preferentially uplifted. Finally, future directions to refine our knowledge of dust emissions using satellite retrievals are proposed.

\section{DESCRIPTION OF DUST SUSPENSION IN THE ATMOSPHERE}

There has been and still is made an intense effort to characterise the generation and transport of dust through experiments using wind tunnel systems to create dust uplift (Gillette 1978, 1999). These studies have shown that a wide range of factors influence dust generation on a micrometeorological scale. These factors include soil composition, soil moisture, surface conditions, and the wind velocity (Marticorena and Bergametti 1995, Marticorena et al. 1997). Emission schemes based upon soil parameters observed in-situ such as local roughness height and the 
density of obstacles (Marticorena et al. 1999) have improved the representation of dust sources in large-scale models. But the application of such schemes to global scales is limited by the availability of data characterizing surface features in arid and semi-arid regions. Due to this lack of available data, global models have identified the location of dust sources based on the soil moisture content (Joussaume 1990), the location of deserts from a vegetation dataset (Genthon 1992ab, Mahowald et al. 1999), the location of sparsely vegetated area and the soil texture from vegetation and soil data sets (Tegen and Fung 1994), or the distribution of dust storm frequencies over arid regions (Dentener et al. 1996).

Before we proceed in the description of the mobilisation of dust, we need to give the definition of a few key concepts:

Saltation layer. Layer of a few tens of centimeters depth near the surface where soil grains from 60 to $2000 \mu \mathrm{m}$ undergo bombardment from other grains creeping along the surface. The bombardment, also called "saltation", dislodges fine particles (with a diameter of less than $60 \mu \mathrm{m}$ ) that can be transported over long distances away from sources.

Horizontal flux. Total amount of dust-related material set in motion in the saltation layer per unit cross section per unit time $\left(\mathrm{kg} \cdot \mathrm{m}^{-2} \cdot \mathrm{s}^{-1}\right)$.

Vertical flux. The fraction of the horizontal flux constituted by fine particles that are transported vertically when the drag momentum exceeds gravitational settling.

Aggregates. Particles in soil are formed of aggregates that include a clay fraction and a non-clay fraction composed by order of importance of quartz, calcite, dolomite, feldspar, halite, gypsum and iron oxides.

Friction velocity. The friction velocity $\left(\mathrm{m} . \mathrm{s}^{-1}\right)$ is the square root of the ratio of wind shear stress to air density.

Threshold friction velocity. The threshold friction velocity is the minimum friction velocity necessary to set soil particles in motion and initiate the saltation movement.

Roughness height. The length scale $(\mathrm{m})$ that characterizes the loss of wind momentum attributable to roughness elements. 
Non-erodible elements. Elements such as stones that affect the ability to uplift dust from the surface are non-erodible elements.

Crusting. Crusting of the surface occurs when salt crystal formation, hydrate formation or bacterial activity occurs. Such crusts prevent any uplifting of soil grains

\subsection{Existing schemes for dust generation}

Two main phenomena are at play to determine when and if dust will be transported out of the surface layer. The most important are: first, the presence of erodible material which can be the result of processes that have occurred over geological time scales; and second, the wind's shear stress on the surface that provides the energy momentum to set the dust in motion.

The mass of the particles can be computed by integrating the horizontal flux. Both wind tunnel experiments and field work have shown the dependency of this horizontal flux on the wind friction velocity $U_{*}$ (reviewed by Greeley and Iversen 1985). Field measurements of the horizontal flux $G$ over different soil types have documented the dependency of $\mathrm{G}$ on the friction velocity (Figure 1). For models of dust emissions, the expression of the horizontal flux of dust needs to account for the following facts:

First, the dust sets in motion over a terrain only when the friction velocity reaches a minimum threshold called threshold friction velocity. Second, the horizontal flux can be expressed as a function of the power of 3 of the friction wind velocity (Bagnold 1941, Chepil 1951; Gillette 1974, 1978).

Further work (Iversen and White 1982, Raupach 1992, 1994; Raupach et al. 1993, Marticorena and Bergametti 1995, Marticorena et al. 1997, Shao and Leslie 1997, Fécan et al. 1999) have brought attention to the importance of the local properties of the terrain to assess the dust flux. 


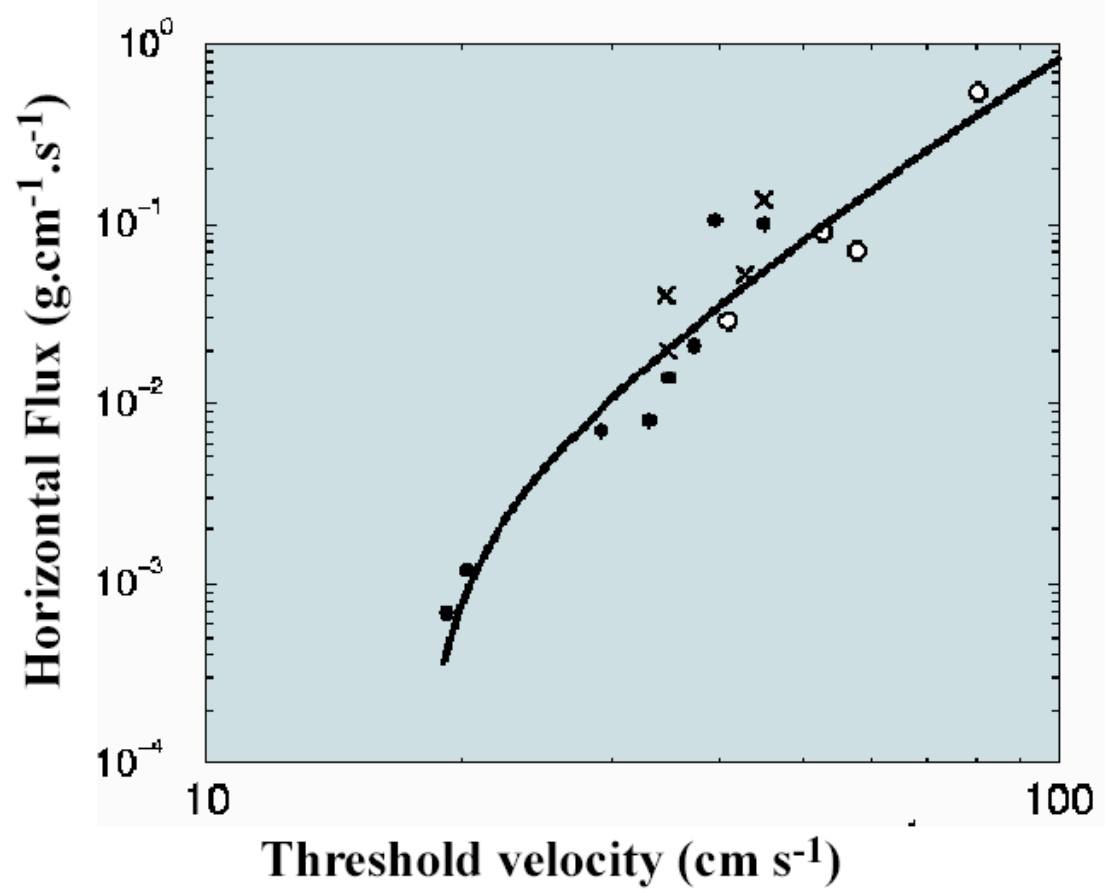

Figure 1. Dust horizontal flux, $\mathrm{G}$, as a function of the threshold friction velocity, $\mathrm{u}^{*}$. The measurements made by Gillette (1974) were done for soils with different size distribution (resp. closed circles, open circles and crosses). The fitted line is a horizontal flux, $\mathrm{G}=1$.e- $6 \mathrm{u}_{*}^{2}\left(\mathrm{u}_{*}-18\right)$.

The properties important for the horizontal flux formulation are: the diameter of soil particles, the obstacles formed by non-erodible elements and the crusting of the soil. From these studies, the horizontal flux of dust resulting from the wind shear stress can be expressed by Equation 1:

$$
G=\int_{0}^{\infty} C\left(D_{p}\right)\left(u_{*}\left(u, z_{0}\right)\right)^{2}\left(u_{*}\left(u, z_{0}\right)-\frac{u_{t h}^{*}\left(D_{p}, \rho, u, q_{S}\right)}{A \gamma}\right) \cdot d D_{p}
$$

where $D_{p}$, is the particle diameter of soil particles; $C\left(D_{p}\right)$ is the emission factor $\left(\mathrm{kg} . \mathrm{s}^{2} . \mathrm{m}^{-5}\right) ; q_{s}$, is the soil wetness; $A$ is a dimensionless wind attenuation factor due to non-erodible elements at the surface; $z_{0}$ is the local roughness height; $\rho$ is the soil grain density; $\gamma$ is a dimensionless factor that accounts for crusted surfaces; $u *$ represents the friction velocity and $u^{*}{ }_{t h}$, the 
threshold friction velocity. Note that this expression needs to be integrated over all the values of soil particle diameter to get a total aerosol mass flux.

Since there is very little information available to correctly estimate local roughness heights over most deserts, the assumption is often made that the friction velocity is proportional to the wind at $10-\mathrm{m}$. Hence the following simple equation which stems from the simplification of equation 1 :

$$
F=C . u_{*}^{2}\left(u_{*}-u_{t h}^{*}\right)
$$

is replaced by

$$
F=C^{\prime} \cdot u^{2}\left(u-u_{t h}\right)
$$

where friction velocity and threshold friction velocity are replaced by $\mathrm{u}$, the wind at $10-\mathrm{m}$ height and the threshold velocity at 10-m height (Joussaume 1990, Tegen and Fung 1994, Nickovic and Dobricic 1996, Mahowald et al. 1999). The choices of emission factors and threshold velocities in regional and global models are summarized in Table 1.

Equation 3 allows the computation of the vertical flux of dust as a function of two parameters: an emission factor $C$, which controls the total amount of dust injected over the time period, and a threshold velocity which controls the frequency of occurrence of dust episodes. Observational information on the frequency of storms may provide information on the threshold velocity. However, a quantitative assessment of the different formulations of dust has been long hampered by the lack of observations of the exact geographical extent of dust episodes. Remote sensing using satellite has allowed great advances in the last few years. First, several types of satellite retrievals have allowed the detection of dust over oceanic surfaces (the Meteorological Satellite (METEOSAT), the Advanced Very High Resolution Radiometer (AVHRR), the Total Ozone Mapping Spectrometer (TOMS)) and, more recently over land, TOMS, and the Lidar-In-space Technology Experiment (LITE). These observations have shown that a constant emission factor cannot correctly simulate the different dust clouds observed over desert regions as different as Asian, African, Australian Deserts or from North America (Marticorena 1995).

Table 1. Comparison of the different dust sources that have been used for global or regional simulations. 


\begin{tabular}{|c|c|c|c|c|}
\hline & $\begin{array}{c}\mathrm{U}^{*}{ }_{\text {thresh }} \\
\text { threshold } \\
\text { velocity }\end{array}$ & $\begin{array}{c}\mathrm{C} \\
\text { Emission } \\
\text { factor }\end{array}$ & $\begin{array}{l}\text { Global emission } \\
(\mathrm{Mt} / \mathrm{yr})\end{array}$ & Remarks \\
\hline $\begin{array}{l}\text { Marticorena and } \\
\text { Bergametti } \\
\text { (1995) }\end{array}$ & $f\left(D_{p}, u^{*}, z_{0}\right)$ & $\begin{array}{l}f\left(D_{p}\right) \text { for } \\
D p<20 \mu \mathrm{m}\end{array}$ & & $\begin{array}{l}\mathrm{z}_{0}, \mathrm{D}_{\mathrm{p}}: \text { mapped } \\
\text { over Sahara }\end{array}$ \\
\hline $\begin{array}{l}\text { Shao and Leslie } \\
\text { (1997) }\end{array}$ & $\mathrm{f}\left(\mathrm{D}_{\mathrm{p}}, \mathrm{z}_{0}\right)$ & $f\left(D_{p}\right)$ & & $\begin{array}{l}\mathrm{z}_{0}, \mathrm{D}_{\mathrm{p}} \text { : mapped } \\
\text { over Australia }\end{array}$ \\
\hline $\begin{array}{l}\text { Nickovic and } \\
\text { Dobricic (1996) }\end{array}$ & $0.5 \mathrm{~m} \cdot \mathrm{s}^{-1}$ & calibrated & & \\
\hline $\begin{array}{l}\text { Tegen et al. } \\
\text { (1996) }\end{array}$ & $6.5 \mathrm{~m} \cdot \mathrm{s}^{-1}$ & calibrated & $\begin{array}{c}1200 \text { for } \mathrm{Dp}< \\
20 \mu \mathrm{m} ;\end{array}$ & \\
\hline Genthon (1992b) & $0 \mathrm{~m} \cdot \mathrm{s}^{-1}$ & $0.7 \mu \mathrm{g} \mathrm{s}^{2} \mathrm{~m}^{-5}$ & 8000 & \\
\hline $\begin{array}{l}\text { Mahowald et al. } \\
\text { (1999) }\end{array}$ & $5 \mathrm{~m} \cdot \mathrm{s}^{-1}$ & calibrated & $\begin{array}{c}3000 \text { for } \mathrm{Dp}< \\
40 \mu \mathrm{m}\end{array}$ & \\
\hline $\begin{array}{l}\text { Dentener et al. } \\
\text { (1996) }\end{array}$ & \multicolumn{2}{|c|}{ Statistical approach } & $\begin{array}{c}1800 \text { for } \mathrm{Dp}< \\
20 \mu \mathrm{m} ; 15500 \text { for } \\
\mathrm{Dp}<60 \mu \mathrm{m}\end{array}$ & \\
\hline $\begin{array}{l}\text { Ginoux et al. } \\
\text { (2001) }\end{array}$ & $\begin{array}{l}\text { Based upon the } \\
\text { work of } \\
\text { MB95* }\end{array}$ & & $1500-2000$ & $\begin{array}{c}5 \text { year } \\
\text { simulation (see } \\
\text { text) }\end{array}$ \\
\hline $\begin{array}{l}\text { Tegen et al., in } \\
\text { press }\end{array}$ & $\begin{array}{l}\text { Based upon the } \\
\text { work of MB95 }\end{array}$ & & $\begin{array}{l}800-1700, \text { for } \\
\mathrm{Dp}<218 \mu \mathrm{m}\end{array}$ & \\
\hline $\begin{array}{l}\text { Woodward } \\
(2001)\end{array}$ & $\begin{array}{l}\mathrm{f}\left(\mathrm{D}_{\mathrm{p}}\right) \text {, adjusted } \\
\text { empirically }\end{array}$ & $\begin{array}{l}\text { calibrated } \\
\text { after MB95 }\end{array}$ & & \\
\hline This work & $\mathrm{F}$ (soil type) & $\begin{array}{l}\text { calibrated } \\
\text { over } 12 \\
\text { regions (see } \\
\text { text) }\end{array}$ & 688 & $\begin{array}{l}1 \text { year } \\
\text { simulation } \\
\text { (JUL 1996- } \\
\text { JUN 1997) }\end{array}$ \\
\hline
\end{tabular}

*MB95 stands for Marticorena and Bergametti (1995)

Table 1 lists the different emission schemes from detailed ones over restricted regions to global schemes. Formulations on restricted regions include works from Marticorena and Bergametti (1995) and Shao and Leslie (1997) and are based upon information on local soil properties. The unavailability of global maps for local roughness heights, soil grain size distribution and heights of non-erodible elements has led to different approaches based upon information contained in satellite retrievals. Global dust emissions have been estimated using two different methods. One is based on the physics of dust suspension and stems from equation 1, while the second accounts for the statistics of observed dust events.

\section{A GLOBAL FORMULATION OF SOIL EROSION BASED UPON SOIL PROPERTIES}


Here, we describe a formulation of the global dust source that uses information available at the global scale. It extends the domain over which the source was formulated in physical models from Marticorena and Bergametti (1995, hereafter referred to as MB95) and Shao and Leslie (1997). Since the availability of fine particles $(<20 \mu \mathrm{m}$ diameter $)$ is a function of the soil type, we looked for a relationship between soil characteristics and threshold velocity.

Since we did not have available mineralogical information for all the arid and semi-arid areas of study, we used the FAO (Food Agriculture Organisation) database of soil types. The FAO Soil Map of the World (Zobler 1986, FAO 1995) is a complete classification of soils based upon genetic and physical characteristics (particle size, soil thickness). The global map with a resolution of 5' x 5' gives the soil type and granulometry. For this work, the map was regridded with a $1^{\circ} \times 1^{\circ}$ resolution. We establish a correspondence between threshold velocities derived by MB95 (shown in Figure 2) and the different FAO soil types over the same region (not shown).

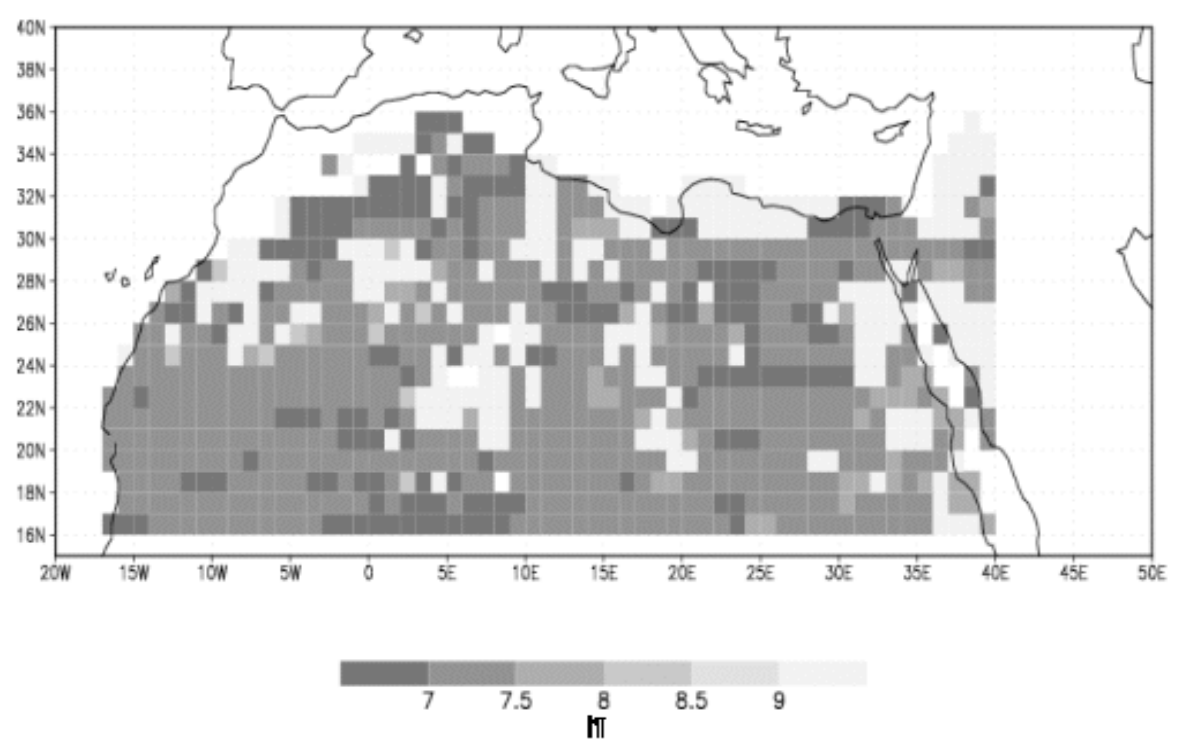

Figure 2. Threshold velocities over North Africa derived by Marticorena and Bergametti (1995). To derive these values of threshold velocities, the authors used the 10 meters wind from ECMWF (European Center for Medium Range Forecasts) with a resolution of $1.125^{\circ} \times 1.125^{\circ}$.

As illustrated in Figure 2, most of the grid cells have associated threshold velocities of less than $14 \mathrm{~m} \cdot \mathrm{s}^{-1}$. One noticeable exception is for very rugged 
terrain. For smooth surfaces, the threshold velocities are never below 6.5 $\mathrm{m} \cdot \mathrm{s}^{-1}$.

Figure 3 presents all the threshold velocities as a histogram. Three different values dominate the distribution: 7.5, 12 and $20 \mathrm{~m}_{\mathrm{s}} \mathrm{s}^{-1}$. The dominant soil over the region of Figure 2 is Yermosol for which the median threshold velocity is $7.5 \mathrm{~m} . \mathrm{s}^{-1}$. This soil type is composed of fine particles. Where yermosols cover more than $90 \%$ of the $1^{\circ} \times 1^{\circ}$ square, the threshold velocities lie in a very narrow range $\left(7.2-7.6 \mathrm{~m} . \mathrm{s}^{-1}\right)$. In other regions where yermosols are not dominant, much higher threshold velocities are computed.

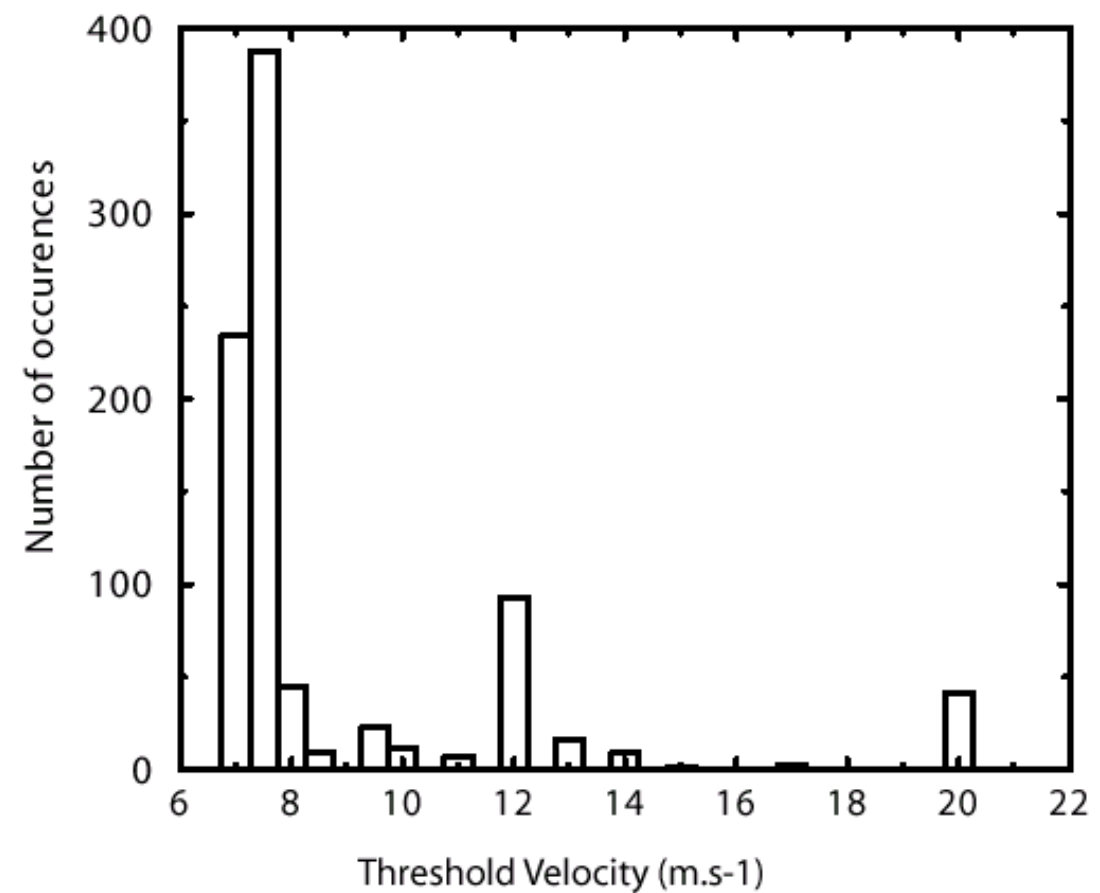

Figure 3. Histogram of the threshold velocities reproduced in Figure 2.

Lithosols have a median value for threshold velocity of $12 \mathrm{~m} \cdot \mathrm{s}^{-1}$. These areas are covered by large blocks of stones and erodible material is rare where these soils dominate. Xerosols are found in semi-arid regions such as in South Africa or over rugged terrains, as in the Atlas mountains. Erosion occurs very seldomly from these soils and they favor a scarce vegetation and contain organic matter. This soil type is the only one for which the median threshold velocity reaches $20 \mathrm{~m} \cdot \mathrm{s}^{-1}$. 
Finally, dust uplift occurs seldomly in regions where slopes are present. This can be explained by the friction velocity necessary to initiate the saltation process as slopes act as an obstacle to its initiation. Flat and montainous terrain were distinguished upon the slope criteria, the slope was used as a criteria to increase the threshold velocity. For regions with slopes between 10 and $20^{\circ}$, the threshold velocity was arbitrarily increased by $2 \mathrm{~m} \cdot \mathrm{s}^{-1}$. For regions with slopes greater than $20^{\circ}$, threshold velocities were increased by 4 m.s ${ }^{-1}$. Only $5 \%$ of the arid regions are affected by these criteria. The exact increment of threshold velocity as a function of slope deserves a more thorough study.

Table 2. Median threshold velocities for the dominant FAO soil types over arid and semi-arid regions.

\begin{tabular}{|c|c|}
\hline Soils type or slope & Threshold velocity $\left(\mathrm{m} . \mathrm{s}^{-1}\right)$ \\
\hline Ferric soil present & \\
Xerosol dominant & $\infty$ (no mobilization) \\
Regosol dominant & $\infty$ (no mobilization) \\
Lithosol dominant & 12.0 \\
Lithosol present & 12.0 \\
Salts flats present & 10.0 \\
Sand dunes dominant & 10.0 \\
Yermosols & 6.5 \\
Fluvisols & 7.5 \\
Slope in excess of $20^{\circ}$ & 7.5 \\
Slope in excess of $10^{\circ}$ & $\mathrm{U}_{\text {thresh }}=\mathrm{U}_{\text {thresh }}+4$ \\
\end{tabular}

The next step is to derive the threshold velocities for all arid and semi-arid areas over the globe. Here we assume that the threshold wind velocities from MB95 can be extrapolated for all regions with similar soil characteristics. For each soil class that covers more than half of the area of a $1^{\circ} \times 1^{\circ}$ square, the threshold velocity is assigned (shown in Figure 2). The median value of the threshold velocity is then derived for each FAO soil class. This median threshold velocity presented in Table 2 is then applied over the globe using the World Map of Soil from the FAO. In most areas, the threshold velocity is equal to $7.5 \mathrm{~m} . \mathrm{s}^{-1}$, which is a higher value than proposed in most global simulations (see Table 1). Figure 4 illustrates the distribution of threshold velocities derived. 


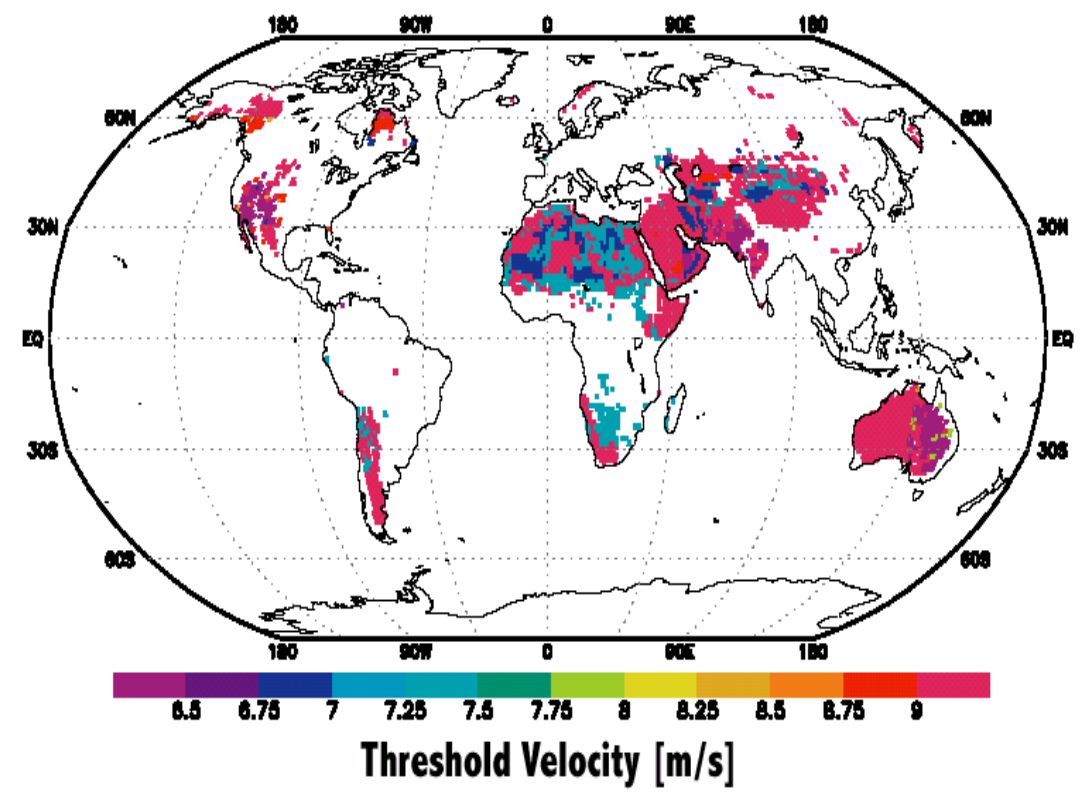

Figure 4. Global map of threshold velocities over arid and semi-arid areas. Soil types were used to infer threshold velocities representative of the FAO soil types. The global FAO map was then used to affect the threshold velocities to soil types for other areas over the world.

\subsection{Derivation of the vertical flux}

Dust emissions mainly occur at high wind speeds: below the threshold velocity, no emission occurs whereas above this threshold, the vertical flux (like the horizontal flux) is proportional to the wind speed cubed (Shao et al. 1993). In order to estimate the vertical emission flux, the emission factor (C' from equation 3 ) needs to be derived.

These estimates had to be derived independently from the method used to derive threshold velocities, hence they had to be derived without using the FAO soil map. The emission factors were obtained by estimating an optical depth from the aerosol index.provided by the TOMS satellite. The semiquantitative TOMS (Total Ozone Mapping Spectrometer) Absorbing Aerosol Index is a unique satellite archive that provides a quasi-daily global coverage of desertdust occurrence (Hermann et al., 1997) and have recently been used to locate major dust sources (Prospero et al., 2002) and to monitordust optical thickness (DOT) over land and ocean (Chiappello et al., 2002; Torres et al., 1998). In contrast to previous modelling efforts that derive a global strength for dust emissions (Tegen et al. 1996 or Mahowald 
et al. 1999), we chose twelve large regions on the basis that seasonality, altitude of dust transport and the mineral composition of dust were characteristic of a particular region. These regions and their locations are listed in Table 3. The emission factors were derived to ensure that the annual mean simulated optical depth equals the one deduced from TOMS retrievals. For this, TOMS aerosol index has to be linked to the optical thickness.

Table 3. Location of source regions and source strength derived based upon TOMS aerosol index.

\begin{tabular}{|l|l|c|}
\hline REGIONS & \multicolumn{1}{|c|}{$\begin{array}{l}\text { GEOGRAPHICAL LOCATION } \\
\text { For the comparison with TOMS }\end{array}$} & $\begin{array}{c}\text { Emission Factor } \\
\mathrm{C} \\
\left(\mu \mathrm{g} . \mathrm{s}^{2} \mathrm{~m}^{-5}\right)\end{array}$ \\
\hline Sahara & $\begin{array}{l}\text { Latitudes: } 14^{\circ} \mathrm{N} \text { and } 30^{\circ} \mathrm{N} \\
\text { Longitudes: } 10^{\circ} \mathrm{W} \text { and } 28^{\circ} \mathrm{E}\end{array}$ & 0.37 \\
\hline Sahel & Lat.: $9^{\circ} \mathrm{N}: 14^{\circ} \mathrm{N}$, Long.: $15^{\circ} \mathrm{W}: 10^{\circ} \mathrm{E}$ & 0.28 \\
\hline Takla-Makan & Lat.: $37^{\circ} \mathrm{N}: 42^{\circ} \mathrm{N}$, Long.: $75^{\circ} \mathrm{E}: 90^{\circ} \mathrm{E}$ & 1.80 \\
\hline Gobi & Lat.: $39^{\circ} \mathrm{N}: 45^{\circ} \mathrm{N}$, Long.: $95^{\circ} \mathrm{E}: 110^{\circ} \mathrm{E}$ & 0.15 \\
\hline Kyzil Kum & Lat.: $35^{\circ} \mathrm{N}: 43^{\circ} \mathrm{N}$, Long.: $55^{\circ} \mathrm{E}: 63^{\circ} \mathrm{E}$ & 0.17 \\
\hline Kara Kum & Lat.: $35^{\circ} \mathrm{N}: 43^{\circ} \mathrm{N}$, Long.: $64^{\circ} \mathrm{E}: 68^{\circ} \mathrm{E}$ & 0.34 \\
\hline Kalahari & Lat.: $19^{\circ} \mathrm{S}: 30^{\circ} \mathrm{S}$, Long.: $18^{\circ} \mathrm{E}: 26^{\circ} \mathrm{E}$ & 0.25 \\
\hline USA & Lat.: $33^{\circ} \mathrm{N}: 40^{\circ} \mathrm{N}$, Long.: $118^{\circ} \mathrm{W}: 108^{\circ} \mathrm{W}$ & 0.32 \\
\hline Saudi Arabia & Lat.: $15^{\circ} \mathrm{N}: 25^{\circ} \mathrm{N}$, Long.: $43^{\circ} \mathrm{E}: 57^{\circ} \mathrm{E}$ & 0.17 \\
\hline Thar Desert & Lat.: $22^{\circ} \mathrm{N}: 27^{\circ} \mathrm{N}$, Long.: $70^{\circ} \mathrm{E}-78^{\circ} \mathrm{E}$ & 1.57 \\
\hline Australia & Lat.: $23^{\circ} \mathrm{S}: 30^{\circ} \mathrm{S}$, Long.: $120^{\circ} \mathrm{E}: 142^{\circ} \mathrm{E}$ & 0.08 \\
\hline Somalia & Lat.: $5^{\circ} \mathrm{N}: 10^{\circ} \mathrm{N}$, Long.: $45^{\circ} \mathrm{E}: 53^{\circ} \mathrm{E}$ & 0.04 \\
\hline
\end{tabular}

Herman et al. (1997) have recently used the data from TOMS on the NIMBUS-7 to map the distribution of absorbing aerosols. Absorbing aerosols are composed mainly of black carbon (i.e., soot) emitted primarily from biomass burning regions, and of mineral dust. Prospero et al. (2002) examined a 13-year period (1980-1992) of TOMS absorbing aerosol product for evidence of persistent dust sources. The TOMS data (Herman et al. 1997) show that on a global scale the dominant sources of mineral dust are all located in the northern hemisphere, mainly in north Africa, the Middle East, central Asia and the Indian subcontinent. TOMS also shows large seasonal changes in dust distribution patterns. 


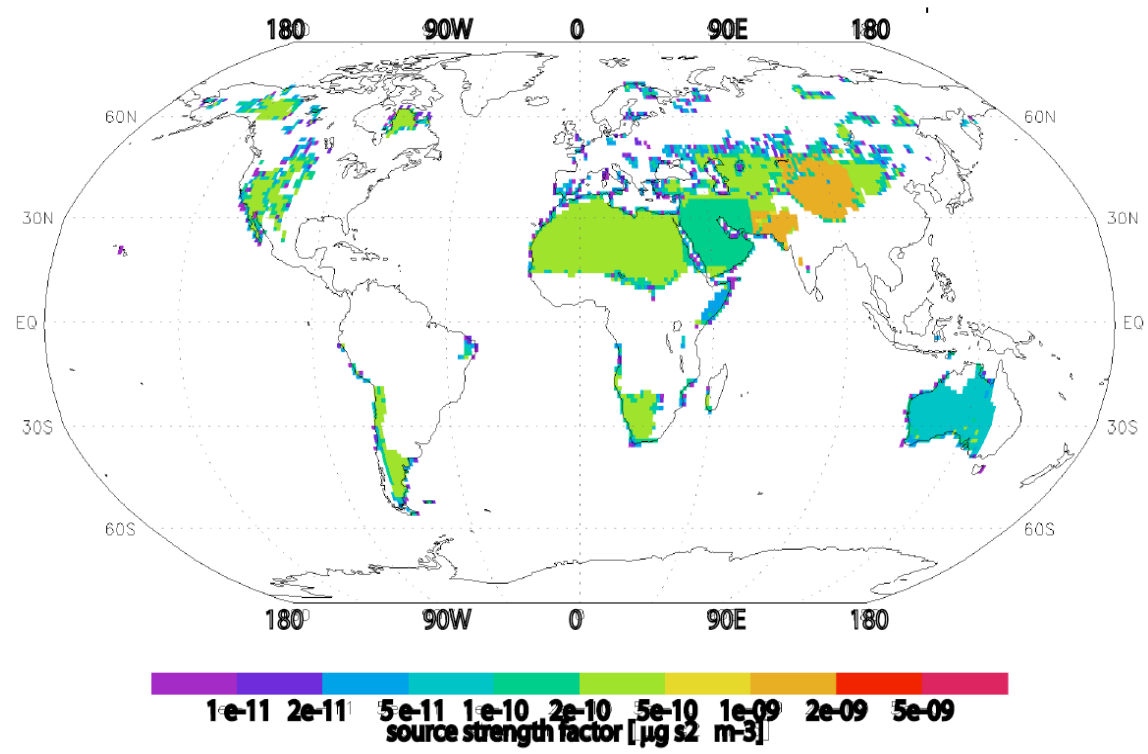

Figure 5. Global distribution of source strength factors $\left(\mathrm{kg} \mathrm{m}^{-5} \mathrm{~s}^{2}\right)\left(\mathrm{C}^{\prime}\right.$ in equation 3$)$ derived by calibrating the model derived optical depth to the optical depth corrected from the TOMS aerosol index. The comparison was made for 1990 and these coefficients are weighted by the fraction of erodible land of each model grid box.

In order to deduce an optical depth from TOMS aerosol index (AI), we assumed that dust is distributed vertically following the profiles of a oneyear global dust simulation. The simulation used the TM3 model with a $3.75^{\circ} \times 5^{\circ}$ horizontal resolution and 19 layers in the vertical (Heimann 1995), with parameterisations for wet and dry deposition from Guelle et al. (2000). The meteorological fields for the simulation were extracted from the European Center for Medium Range Forecast reanalysis for the year 1990. The vertical distribution of the dust profile was saved daily at every model grid point. To compute the aerosol depth, the relationships that Hsu et al. (1999) gave for four altitudes $(0.5,1.5,3.0$ and $6.0 \mathrm{~km})$ were applied to infer an optical thickness from TOMS Aerosol Index for 1990. Less than 10\% of the dust mass resides above the higher altitude $(6 \mathrm{~km})$, and the relationships were interpolated linearly between these altitudes. The emission factors were derived for the 12 different arid regions shown in Figure 5 and listed in Table 4 by adjusting $C^{\prime}$ to obtain the same simulated yearly mean optical depth as derived from TOMS. 
Table 4. Emission factors.

\begin{tabular}{|l|c|c|}
\hline TYPE & $\begin{array}{l}\text { \# days during which source is } \\
\text { inhibited }\end{array}$ & $\begin{array}{l}\text { Threshold precipitation } \\
\text { amount over the period } \\
(\mathrm{mm})\end{array}$ \\
\hline $\begin{array}{l}\text { Warm } \\
\text { temperature/ } \\
\text { Low clay content }\end{array}$ & 1 & 0.82 \\
\hline $\begin{array}{l}\text { Warm } \\
\text { temperature/ } \\
\text { High clay content }\end{array}$ & 3 & 2.46 \\
\hline $\begin{array}{l}\text { Cold temperature/ } \\
\text { Low clay content }\end{array}$ & 4 & 3.28 \\
\hline $\begin{array}{l}\text { Cold temperature/ } \\
\text { High clay content }\end{array}$ & 8 & 6.86 \\
\hline
\end{tabular}

The simulated dust emissions from the model were computed with the above derived threshold velocities using the ECMWF $10 \mathrm{~m}$ winds at a $1.125^{\circ} \times 1.125^{\circ}$ resolution. For most regions, the emission factor lies within a factor of 3 of the constant value of $0.7 \mu \mathrm{g} . \mathrm{s}^{2} \cdot \mathrm{m}^{-5}$ used by Tegen and Fung (1994). This emission factor is exceeded significantly for the Thar and Takla-Makan deserts, and considerably lower over Australia and Somalia. The emission factor from the African deserts with a low elevation (few hundred meters) is systematically low (between 0.25 and $0.37 \mu \mathrm{g} . \mathrm{s}^{2} \mathrm{~m}^{-5}$ ). Figure 6 shows a comparison of the optical depth over the desert (near sources) derived from TOMS, and recalculated from the TM3 model. Error analysis of optical properties derived from backscattered radiances in the UV have been discussed in more details by Torres et al. (1998). Their analysis shows that the error of dust optical thickness due to uncertainty in aerosol altitude and cloud contamination could be as high as $65 \%$ and $40 \%$, respectively. Due to the large footprint of TOMS measurements $(50 \mathrm{~km}$ at nadir), sub-pixel cloud contamination is quite frequent and unfortunately difficult to resolve. By selecting data with low observed reflectance, it can be assumed that the data are mostly cloud free (Torres et al. 2002:). 


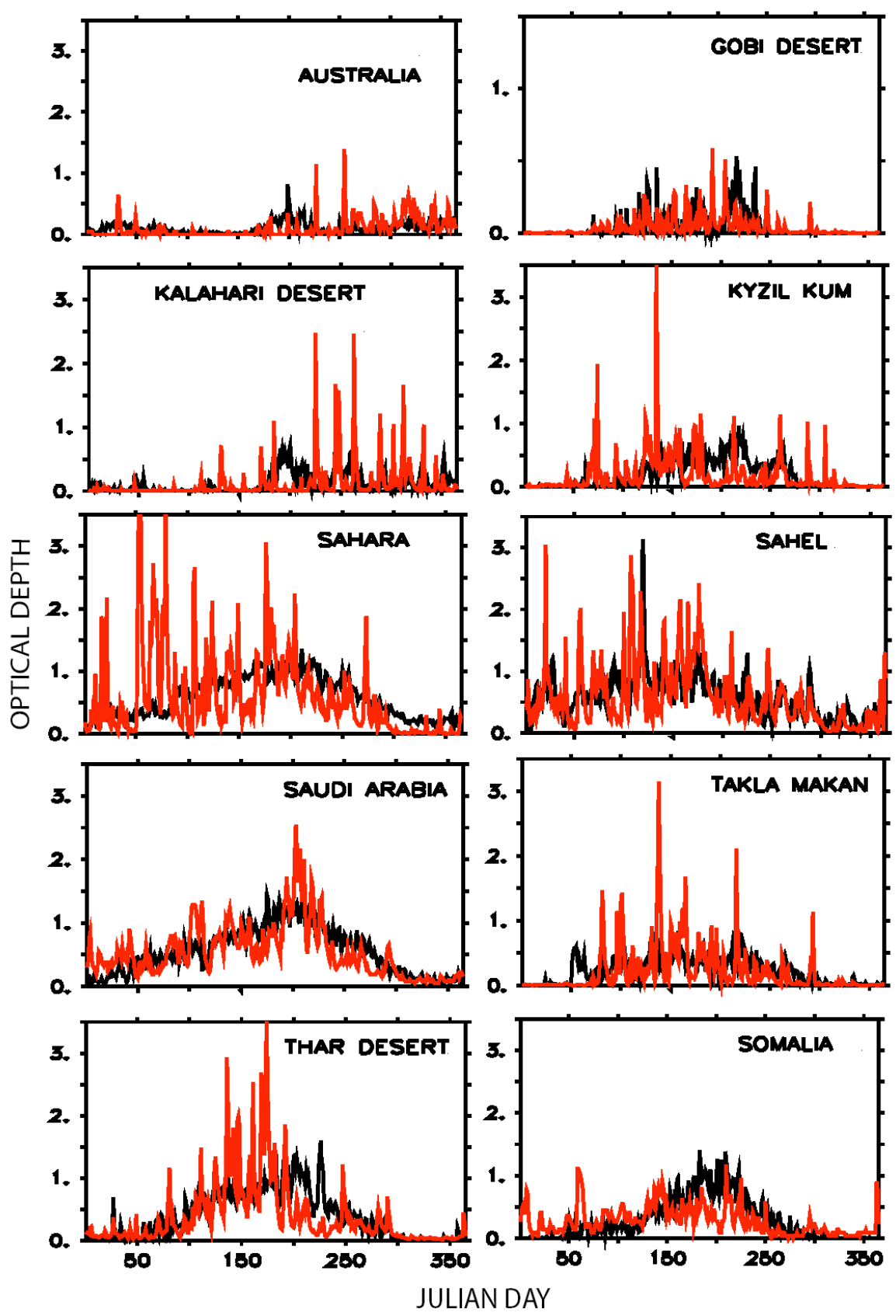

Figure 6. Time series of optical depth over the areas listed in Table 3 for 10 of the 12 deserts. The black line represents TOMS-derived optical depth corrected to account for wavelength and the altitude dependence of TOMS retrieved signal. The red line is the modeled optical depth. No cloud screening was applied on the model results. 
The TOMS satellite has a polar orbit with a local passing time around 11:00 am with a shift of about 30 minutes varying from year to year. When using TOMS data, it is important to recognize that the local passing time is not necessarily representative of a time dependent physical property. Statistical analysis of meteorological fields show that the most likely period of dust emission varies from source to source. The TOMS passing time does not necessarily coincide with the maximum activity. Therefore, comparison of dust emission using TOMS data will be biased towards the sources with their peak activity corresponding with TOMS passing time. For example, Ginoux et al. (2001) show that the Bodele depression which appeared as the "hot spot" of TOMS data (Prospero et al. 2002) has also the most frequent gusty winds around 11:00 am.

The seasonality of optical depth shown in Figure 6 depends upon: 10m wind speed, precipitation and freezing surface temperature. We capture well this seasonality and the frequency of occurrence of the episodes for most deserts with the noticeable exception of the Sahara. Over the Sahara, the simulated emissions are stronger than the optical thickness derived from TOMS indicates. Over the Sahel region, the period of study to calibrate the source emission strength was restricted to April to September, in order to be relatively free of the carbonaceous aerosol influence resulting from biomass burning.

Individual peaks are well captured over all deserts except the Sahara, where the the high background optical depth and rather smooth variations are not so well represented in the simulation.

Since to our knowledge there are no such comparisons of daily time series, it is difficult to show the improvement of this approach compared to other formulations of global dust sources.

\subsection{Effect of precipitation on dust emissions}

Precipitation and the subsequent increase in soil moisture enhance the cohesive forces between soil grains, and will prevent emissions until the upper millimetres of soil become sufficiently dry. The two main factors that affect this enhanced adhesion of soil grain are the amounts of clay in the soil and the surface air temperature. Shao et al. (1996) discuss the dependence of the threshold velocity on soil moisture and Fecan et al. (1999) propose a relationship between threshold wind velocity and soil moisture and texture. 
The retention of water by soils in arid and semi-arid regions is controlled to a large extent by its clay content. Therefore, we based the formulation of the effect of precipitation and soil freezing upon two easily accessible variables: soil clay content which controls the retention of water, and monthly mean temperature which allows the distinction between cold and warm deserts. Two deserts were selected for establishing the period during which a desert cannot emit dust after a precipitation event: the Gobi desert for its cold temperatures and the Thar desert for its occurrence of precipitation in a warm setting. Next, we had to establish a threshold number of days over which dust emission is inhibited after a precipitation event. The duration of this period was established for 4 possible cases to distinguish small and large clay content in soils, as well as cold and warm surface temperatures.

The clay content from the FAO database was considered high (resp. low) if it exceeded $10 \%$ by mass (resp. was lower than). The threshold between high and low temperature is set at $20^{\circ} \mathrm{C}$. The periods with no dust emissions were calculated using the TOMS AI over the two deserts (Gobi and Thar deserts) by matching the number of occurrences of dust events over the year. The best match was found for periods of 1, 3, 4 and 8 days for respectively warm temp./low clay, warm temp./high clay, cold temp./low clay, cold temp./high clay. In addition, soil erosion is totally inhibited upon freezing. If no more than $0.82 \mathrm{~mm} /$ day (corresponding to $300 \mathrm{~mm} /$ year) of precipitation occurred during these periods, then the emissions of dust were allowed to resume thereafter.

\subsection{Comparison to an alternative approach}

The previous section described an approach that uses global soil datasets to extend threshold wind velocities calculated using detailed datasets in north Africa. This section describes an alternative approach, based on the observation that the highest TOMS AI values are observed over regions that are topographically lower than nearby regions (e.g. Prospero et al. 2002), in addition to being dry and unvegetated. In this methodology, the threshold wind velocities are assumed to be constant everywhere, but a topographic factor is used to parameterize the relative soil erodibility. The identification of dust sources with topographical low has simplified the modeling of dust and has lead to improved results, compared to approaches when preferential sources were not identified (Ginoux et al. 2001, Tegen et al., in press). Ginoux et al. (2001) model global dust sources using a topographical factor in the source function, wherein the source emissions are weighted by comparing the elevation of each 1 by 1 degree grid point with the surrounding hydrological basin. 

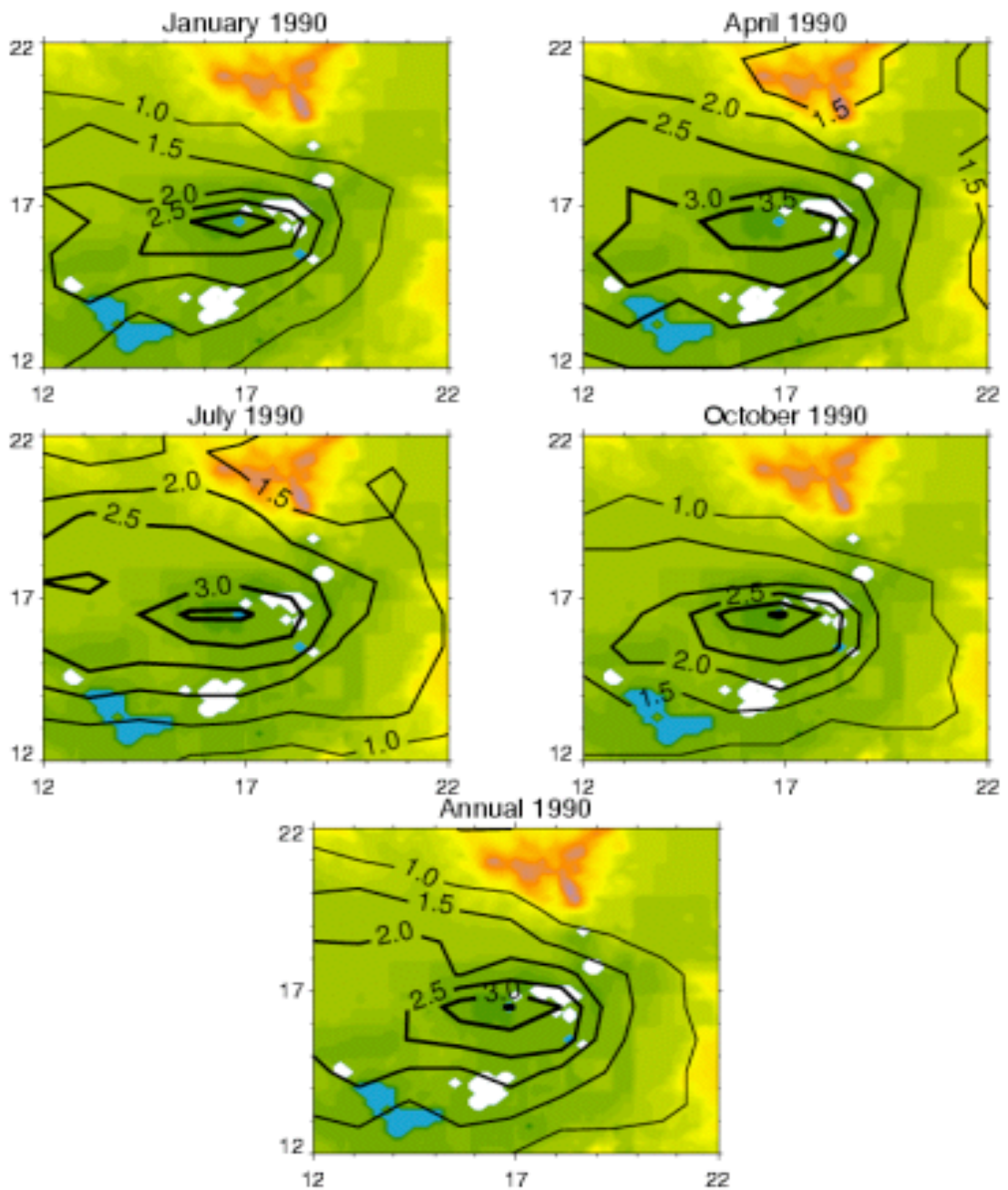

Figure 7. TOMS Aerosol distribution for 1990 (bold lines) and the orography of the Bodele Depression which lies south of the Tibesti and west of the Ennedi mountains. The blue area are lakes and the white spots are dry lakes or salt pans.

Figure 7 shows the monthly mean TOMS Aerosol Index distribution for 1990 (bold lines) and the orography of the Bodele Depression, which lies south of the Tibesti and west of the Ennedi mountains. The blue area are lakes and the white spots are dry lakes or salt pans. This figure shows, that the entire basin is filled with dust all year long. This is in agreement with visibility data from meteorological stations (Mbourou et al. 1997), which 
show a high frequency of visibility reduction during all seasons except in autumn, when the rate decreases somewhat. Based on these elements, Ginoux et al. (2001) have defined a global distribution of dust sources by using the surface topographic features. They assume that a basin with pronounced topographic variations contains large amounts of sediments, which are accumulated essentially in the valleys and depressions, and over a relatively flat basin the amount of alluvium is homogeneously distributed. A source function is then calculated from a simple formula expressing the relative altitude of any grid point in a basin of fixed size. Only land surface with bare soil is considered as possible dust source.

A cursory examination of maps reveals that the geometry of the TOMS aerosol distributions over a specific region can often be associated with playas (undrained desert basins). There is a considerable evidence that playas can be an important source of dust (Reheis 1997), but from the viewpoint of large-scale dust processes the playas themselves are not necessarily the dominant sources within individual regions. Playa surfaces are often hardened and compacted, and they are often cemented with salt minerals. Rather the close association of playas with TOMS "hot spots" is a manifestation of the general type of environment that is conductive to dust production: that is, arid basins that have a recent pluvial history and which today receive relatively small amounts of water either directly or from runoff. In this regard playas could serve as a convenient marker for potential dust source environments in the present or as evidence of active dust environments in the past. Another major characteristic of many sources is the presence of deep and extensive alluvial deposits, a feature that is consistent with the location of the sources in basins or juxtaposed to topographic highs. During pluvial phases, these basins were flooded and thick layers of sediment were deposited; they are now exposed. Many of the most active TOMS "hot spots" were flooded during the Pleistocene. The prime example is the Lake Chad basin, the largest source of long-range dust in north Africa and possibly the world. 


\section{Source function}

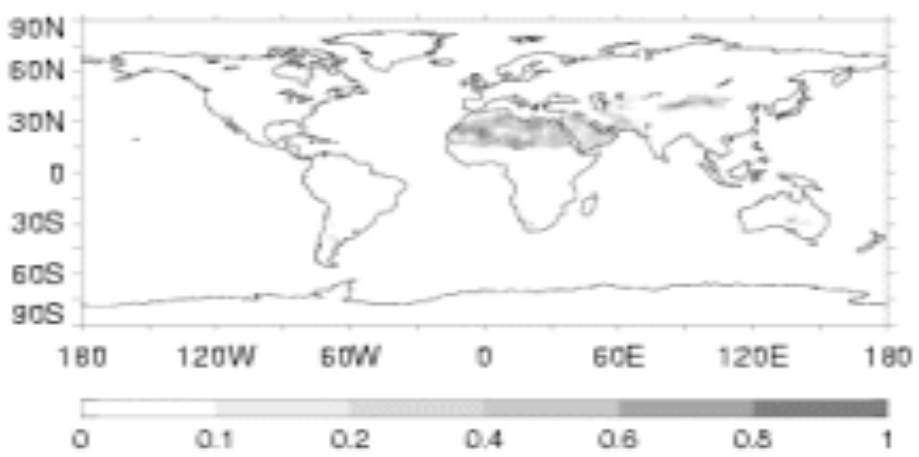

\section{Dust Emission (g. $\left.\mathrm{m}^{2} \cdot \mathrm{yr}^{\prime}\right)$}

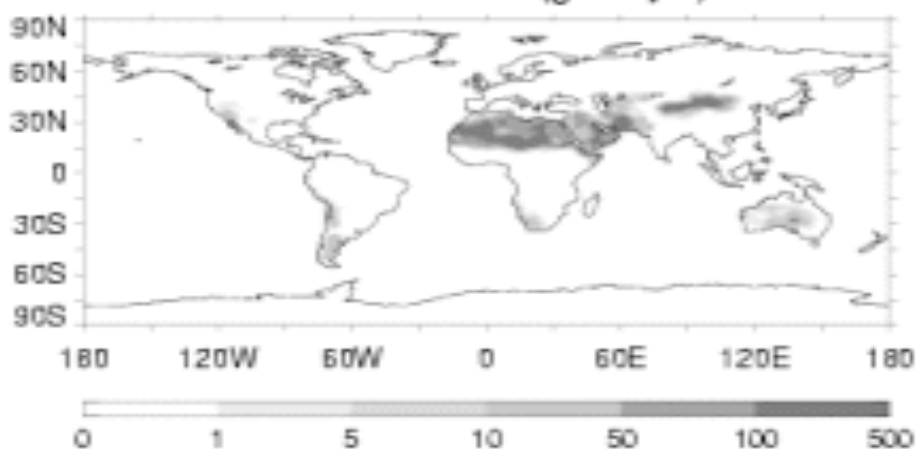

TOMS Aerosol Index

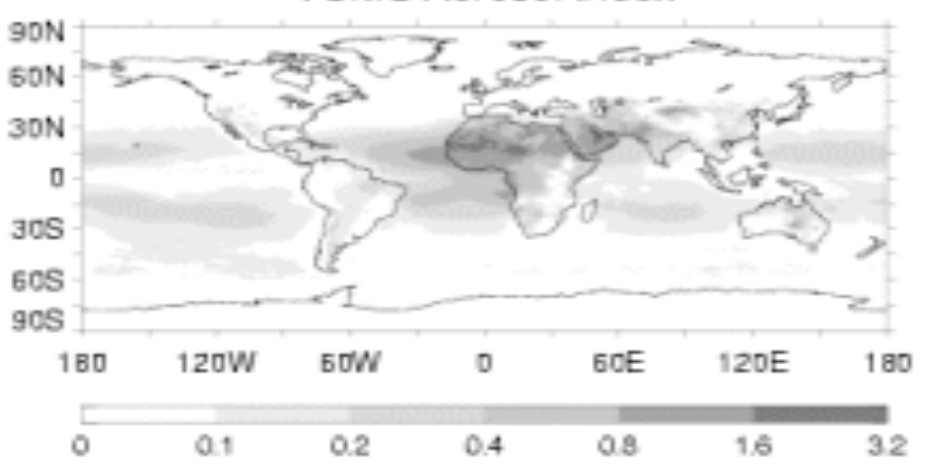

Figure 8. Comparison of model results with in-situ and satellite data indicates that the combination of observed meteorology to drive transport model and a dust sources located in topographic lows with bare soil are key factors to reproduce successfully dust features. 
Figure 8 shows the global distribution of the source function, the calculated dust emission, and the TOMS Aerosol index. Most of the maxima of the source function are collocated with the TOMS "hot spots", identified by Prospero et al. (2002) as major dust sources. The clearest examples are the Tunisian, Libyan, Mauritanian, and Malian sources in the Sahara, the Bodele depression in the Sahel, the Indian source along the Indus valley, the Taklamakan located north of the Himalaya, the lake Eyre basin in Australia, the Salton Sea in southern California, the Altiplano and Patagonia in the Andes, and the Namibian source in southwest Africa.

By using such emissions, Ginoux et al. (2001) are able to reproduce observed global scale dust distribution patterns (Figure 8). The total emission is estimated between 1500 and $2000 \mathrm{Tg} / \mathrm{yr}$ in a five-year simulation. This result is to be compared with emissions of 800 to 1700 $\mathrm{Tg} / \mathrm{yr}$ obtained in Tegen et al. (in press).

\section{PERSPECTIVES TO INFER GLOBAL EMISSIONS OF MINERAL AEROSOL FROM SATELLITE RETRIEVALS}

Currently, two semi-quantitative indices, the TOMS AI and the METEOSAT IDDI (Infrared Difference Dust Index): which makes use of the thermal infrared channel of the geostationary METEOSAT sensor, are the only satellite data currently available on the large scale and for long time periods that provide information on the dust source location and strength. These two indices do not have the same sources of error, and they can thus be viewed as "complementary". So far, no systematic daily comparison of these two indices has been performed.

As revealed from the different studies cited and the work presented in this paper, the TOMS AI archive constitutes an easy-to-use satellite data set for developing/validating schemes of the emission of mineral dust at the global scale. This product however has severe drawbacks in terms of quantitative validation of the dust emissions, since it remains uncertain how well it can be directly linked to the aerosol optical thickness. On the other hand, recent studies suggest that optical thickness can be retrieved with a reasonable accuracy from the AI value (Chiapello and Moulin 2002, Torres et al. 2001). The METEOSAT IDDI (Infrared Difference Dust Index, Legrand et al. 2001), is also problematic to use for quantitative studies. This index is based on the observation in a cloud-free environment of a significant decrease of the brightness temperature, and thus of the IR numeric counts during daytime over arid regions, when dust concentration increases in the atmosphere. This apparent cooling of the surface is due to the attenuation of 
the infrared radiance, emitted by the hot arid soil, by the colder atmospheric dust layer.

The launch of a new generation of more accurate aerosol oriented sensors such as POLDER (POLarization and Directionality of the Earth's Reflectance) and MODIS (Moderate Resolution Imaging Spectroradiometer) at the end of the 90's unfortunately did not yet improve our knowledge on the dust emissions. POLDER was launched in 1996 onboard the Japanese platform ADEOS (ADvanced Earth Orbiting Satellite) and provided data from November 1996 to June 1997. One of its most interesting features for aerosol studies over the continents was to measure the polarisation of the light scattered by the Earth-atmosphere system. Because most of the terrestrial surfaces have a low polarization efficiency and because aerosols strongly polarize the incident solar light, POLDER provided the first high resolution global monitoring of the aerosol optical thickness over the continents (Tanré et al. 2001). This monitoring unfortunately turned out to not be possible for mineral dust because these large $(>1 \mu \mathrm{m})$ and nonspherical particles have a very low polarization efficiency. In a similar manner, the current MODIS algorithm fails in retrieving aerosol optical thickness over deserts because of the too large brightness of the surface in the near infrared. Arid surfaces have, however, some particular optical properties that could be used to improve mineral dust detection over the deserts from MODIS, POLDER or similar multi-spectral and multi-angular sensors. Desert reflectances are relatively low and constant in the blue part of the solar spectrum, so that mineral dust optical thickness could be retrieved directly from blue band measurements using accurate radiative transfer computations. Such a method is currently not used for the operational processing of any sensor, but it has already been tested using POLDER data (Colzy and Bréon, pers. comm.). The land/sea continuity in retrieved aerosol optical thickness obtained for some summertime dust events suggests that realistic optical thickness can be retrieved over deserts, when the viewing geometry is favourable. The main difficulty with this approach is to create a database of clear sky desert reflectances in the blue wavelength domain to be used within the inversion procedure. This may be an interesting option to fill the gap in aerosol optical thickness over the desert and to fulfil the need to monitor dust emissions.

Dust optical thickness could also be a useful product of the forthcoming Lidar in space measurements. CALIPSO-CENA (Cloud-Aerosol Lidar and Infrared Pathfinder Satellite Observations) on the Aqua platform will provide vertical profiles of the dust layers over the desert coincident with MODIS and PARASOL (Polarization and Anisotropy of Reflectances for Atmospheric Sciences coupled with Observations from a Lidar). It would 
thus be most valuable to combine these different data to get the best possible estimates of the dust horizontal and vertical distribution over potential source regions.

It must be emphasized that the aerosol characterisation over the sea surface is much easier and thus much more complete than what can be achieved over bright surfaces such as deserts. POLDER and MODIS, as well as other "ocean colour" oriented sensors such as SEAWIFS (Moulin et al. 2001), can provide relatively accurate information on the particle size distribution and single scattering albedo in addition to the optical thickness. Provided that the source region is not too distant from the coast and that the dust is transported directly towards the ocean, all these information could be used to validate and improve the size distribution of the mineral dust chosen by models in source regions. Another source of information could be provided by the channels around 1 and $2 \mu \mathrm{m}$ from the MODIS (and from the forthcoming MSG), these channels are specific to mineral dust and sea salt and could bring further information on aerosol over the ocean. Most of the aerosols have small sizes compared to these wavelengths and are therefore not detected. For mineral dust, only the largest particles will scatter the incident solar light.

\section{CONCLUSIONS}

Although considerable progress has been made in the last decades in our understanding of the physics of dust emissions, attempts at establishing a global source of dust have been hampered by the lack of information on local soil properties such as soil grain size distribution and local roughness height.

Topographical lows have been shown to act as active dust sources, although their relative importance compared to other surfaces has not clearly been established.

In this paper we propose a global formulation of dust sources based upon a source scheme where threshold velocities and emission factors are computed over arid and semi-arid regions. Threshold velocities were derived by associating a value which was calculated with detailed data in North Africa to each dominant FAO soil type and extrapolated globally. The source strengths of 12 individual arid areas were deduced on the basis of the retrieval of the aerosol optical depth from TOMS data. 
Satellite data have opened the way for validation of dust emission schemes and of atmospheric dust distribution. Where most needed, i.e., in the vicinity of source regions, a reliable quantitative estimate of the aerosol burden remains evasive. Nonetheless, the conjunction of multi-spectral captors and active sensors have created new directions of research for a quantification of the dust emissions.

\section{REFERNCES}

Andreae, M. O., 1995, "Climatic effects of changing atmospheric aerosol levels," in World Survey of Climatology, 16, Future climates of the world, A. Henderson-Sellers, Ed., Elsevier, Amsterdam, 347-398.

Bagnold, R.A., The Physics of Blown Sand and Desert Dunes, Mehuen, London, 265 pp. 1941.

Chepil, W.S., Properties of soil which influrence wind erosion,4: State of dry aggregate structure, Soil Sci., 72, 387-401, 1951.

Chiapello I. and C. Moulin, TOMS and METEOSAT satellite records of the variability of Saharan dust transport over the Atlantic during the last two decades (1979-1997), Geophys. Res. Lett., 29, 17-20, 2002.

Dentener, F. J., G. R. Carmichael, Y. Zhang, J. Lelieveld, and P. Crutzen, Role of mineral aerosol as a reactive surface in the global troposphere, J. Geophys. Res., 101, 22,869-22,889, 1996.

Deuzé J.L., P. Goloub, M. Herman, A. Marchand, G. Perry, S. Susana, and D. Tanré, Estimate of the aerosol properties over the oceans with POLDER, J. Geophys. Res., 105, 15329-15346, 2000.

Falkowski, P. G., R. T. Barber, and V. Smetacek, Biogeochemical controls and feedbacks on Ocean primary production, Science, 281, 200-206, 1998.

Fécan F., B. Marticorena and G. Bergametti, Parametrization of the increase in aeolian erosion threshold wind velocity due to soil moisture for arid and semi-arid areas, Ann. Geophysicae, 19, 149-157, 1999.

Food and Agriculture Organization of the United Nations (FAO-UNESCO) (1995). Digital Soil Map of the World and Derived Properties. Rome, Italy,1995.

Genthon, C., Simulations of the long range transport of desert dust and sea-salt in a general circulation model, in Precipitation, Scavenging and Atmospheric Surface Exchange, ed. S. E. Schwartz and W. G. N. Slinn, pp. 1783-1794, Taylor and Francis, Philadelphia, PA, 1992a. 
Genthon,C. Simulations of desert dust and sea-salt aerosols in Antarctica with a general circulation model of the atmosphere, Tellus, Ser. B, 44, 371-389, 1992b.

Gillette, D. A., On the production of wind erosion aerosol having potential for long range transport, J. Rech. Atmos. 8, 734-744, 1974.

Gillette, D. A., A wind-tunnel simulation of the erosion of soil: Effect of soil texture, sandblasting, wind speed, and soil consolidation on dust production, Atm. Environ., 12, 17351743, 1978.

Gillette, D. A., A qualitative geophysical explantion for "hot-spot" dust emitting source regions, Contr. Atmos. Phys., 72, 67-77, 1999.

Ginoux, P., M. Chin, I. Tegen, J. M. Prospero, B. Holben, O. Dubovik, and S-J Lin, Sources and distributions of dust aerosols simulated with the GOCART model, J. Geophys. Res., 106, 20,255-20,273, 2001.

Greeley R. and J.D. Iversen, Wind as a Geological Process on Earth, Venus, Mars, and Titan, Cambridge University Press, Cambridge, 333 pp., 1985.

Griffin, D. W., V. H. garrison, J. R. Herman, and E. A. Shinn, African desert dust in the Caribebbean atmosphere: Microbiology and public health, Aerobiologia, 17, 203-213, 2001.

Guelle, W., Y. Balkanski, M. Schulz, B. Marticorena, G. Bergametti, C. Moulin, R. Arimoto, and K. D. Perry, Modelling the atmospheric distribution of mineral aerosol: Comparison with ground measurements and satellite observations for yearly and synoptic time scales over the North Atlantic, J. Geophys. Res, 105, 1997-2005, 2000.

Harrison, S. P., K. E. Kohfeld, C. Roelandt, and T. Claquin, The role of dust in climate changes today, at the last glacial maximum an in the future, Earth Sci. Rev., 54, 43-80, 2001.

Haywood, J., and O. Boucher, Estimates of the direct and indirect radiative forcing dir to tropospheric aerosols, Rev. Geophys., 38, 513-543, 2000.

Heimann, M., The global atmospheric model TM2 (model description and user manual), Technical report, Deutsches Klimarechenzentrum, Hamburg, Technical Report No 10, 47 pp., 1995.

Herman, J. R., P. K. Bhartia, O. Torres, C. Hsu, C. Seftor, and E. Celarier, Global distribution of UV-absorbing aerosols from Nimbus 7/TOMS data, J. Geophys. Res., 102, 16,911-16,922, 1997.

Hsu, N. C., J. R. Hermann, O. Torres, B. N. Holben, D. Tanre, T. F. Eck, A. Smirnov, B. Chatenet, and F. Lavenu, Comparisons of the TOMS aerosol index with Sun-photometer aerosol optical depth: Results and applictations, J. Geophys. Res., 104, 6269-6279, 1999.

Husar, R. B., J. M. Prospero, and L. L. Stowe, Characterization of tropospheric aerosols over the oceans with the NOAA Advanced Very High Resolution Radiometer optical thickness operational product, J. Geophys. Res., 102, 16,889-16,909, 1997.

Intergovermental Panel on Climate Change, Climate Change 2001: The Scientific Basis: Contribution of Working Group I to the Third Assessment Report of the Intergovermental Panel on Climate, J. T. Houghton, Y. Ding, D.J. Griggs, M. Noguer, Editors, 2001. 
Iversen, J.D. and J.R. White, Saltation threshold on Earth, Mars and Venus, Sedimentology, 29, 111-119, 1982.

Joussaume, S., Three dimensional simulations of the atmospheric cycle of desert dust particles using a general circulation model, J. Geophys. Res., 95, 1909-1941, 1990.

Legrand M., A. Plana-Fattori, C. N'doumé, Satellite detection of dust using the IR imagery of Meteosat, 1. Infrared difference dust index, J. Geophys. Res., 106, 18251-18273, 2001.

Levin, Z., E. Ganor, and V. Gladstein, The effects of desert particles coated with sulfate on rain formation in the eastern Mediterranean, J. Appl. Metorol., 35, 1511-1523, 1996.

Li X., H.B. Maring, D. Savoie, K. Voss and J.M. Prospero, 1996: Dominance of mineral dust in aerosol light scattering in the North Atlantic trade winds, Nature, 380, 416-419.

Mahowald, N., K. Kohfeld, M. Hansson, Y. Balkanski, S. P. Harrison, I. C. Prentice, M. Schulz, and H. Rodhe, Dust sources and deposition during the last glacial maximum and current climate: A comparison of model results with paleodata from ice cores and marine sediments, J. Geophys. Res., 104, 15,895-15,916, 1999.

Marticorena, B. and G. Bergametti, Modeling the atmospheric dust cycle: 1. Design of a soilderived dust emission scheme, J. Geophys. Res., 100, 16415-16430, 1995.

Marticorena, B., Modeling the production of desert dust in arid and semi-arid regions: development and validation of a computational code for large-scale transport (in French). Ph.D thesis Paris University. 1995.

Marticorena, B., G. Bergametti, D. A. Gillette, and J. Belnap, Factors controlling threshold friction velocity in semi-arid and arid areas of the United States, J. Geophys. Res., 102, 23,277-23,287, 1997.

Marticorena, B., G. Bergametti, and M. Legrand, Comparison of emission models used for large scale simulation of the mineral dust cycle, Contr. Atmos. Phys., 72, 151-160, 1999.

Martin, J.H. and R.M. Gordon, Northeast Pacific iron distributions in relation to phytoplankton productivity, Deep-Sea Res., 35, 177-196, 1988.

Mbourou, G.N., J.J. Bertrand and S.E. Nicholson, The diurnal and seasonal cycles of windborne dust over Africa north of the Equator. J. Appl. Meteor. 36: 265-273, 1997.

Nickovic, S., and Dobricic, S., A model for long-range transport of desert dust, Mon. Wea. Rev., 124, 2537-2544, 1996.

Patial R., Nountain desert silicosis, J. Assoc. Phyis. India, 47, 503-504, 1999.

Prospero, J. M., P. Ginoux, O. Torres,S. Nicholson, and T. Gill, Environmental characterization of global sources of amospheric soil dust identified with the NIMBUS-7 TOMS Absorbing Aerosol Product, Rev. Geophys., 40, 1-31 2002.

Pye, K., Aeolian Dust and Dust Deposits, Academic Press, San Diego, California,1987. 
Raupach, M.R., Drag and drag partition on rough surfaces, Bondary Layer Meteorology, 60, 375-395; 1992.

Raupach, M.R., Gillette D.A. and Leys J.F., The effect of roughness elements on wind erosion threshold, J. Geophys. Res., 98, 3023-3029, 1993.

Raupach, M.R., Simplified expression for vegetation roughness length and zero-plane displacement as function of canopy height and area index, Bondary Layer Meteorol., 71, 211216, 1994.

Reheis, M. C.. Dust deposition downwind of Owens (dry) Lake, 1991-1994: Preliminary findings. Journal of Geophysical Research-Atmospheres, 102, 25999 - 26008, 1997.

Rosenfeld, D. 2000. Suppression of rain and snow by urban and industrial air pollution. Science 287: 1793-1796.

Saxton, K.E., D.G. Chandler, L. Stetler, B. Lamb, C. Clairborn, and B.-H. Lee, Wind erosion and fugitive dust fluxes on agricultural lands in the Pacific Northwest, 2001.

Shao Y., M.R. Raupach, and P.A. Findlater, Effect of saltation bombardment on the entrainment of dust by wind, J. Geophys. Res., 12719-21726, 1993.

Shao Y., M.R. Raupach, and J.F. Leys, A model for predicting eolian sand drift and dust entrainment on scales from paddock to region, Aust., J. Soi. Res., 34, 309-342, 1996.

Shao Y. and L. Leslie, Wind erosion prediction over the Australian continent, J. Geophys. Res., 102, 30091-30105, 1997.

Song C. H., Carmichael, G. R. 2001 A three-dimensional modeling investigation of the evolution processes of dust and sea-salt particles in east Asia, J. Geophys. Res., 106, p. $18,131-18,1542001$.

Tanré D., F.M. Bréon, J.L. Deuzé, M. Herman, P. Goloub, F. Nadal, and A. Marchand, Global observation of anthropogenic aerosols from satellite, Geophys. Res. Lett., 28, 4555-4558, 2001.

Tegen, I., and I. Fung, Modeling of mineral dust in the atmosphere: Sources, transport, and optical thickness, J. Geophys. Res., 99, 22,8970-22,914, 1994.

Tegen, I., and I. Fung, Contribution to the atmospheric mineral aerosol load from land surface modification, Journal of Geophysical Research, 100 (D9), 18,707-18,726, 1995.

Tegen, I., and A. A. Lacis, Modeling of particle size distribution and its influence on the radiative properties of mineral dust aerosol, J. Geophys. Res., 101, 19,237-19244, 1996.

Tegen, I., A.A. Lacis and I. Fung, The influence on climate forcing of mineral aerosols from disturbed soils Nature, 380, 419-422; 1996.

Tegen, I., P. Hollrig, M. Chin, I. Fung, D. Jacob, and J. Penner, Contribution of different aerosol species to the global aerosol extinction optical thickness; estimates from model results, J. Geophys. Res., 102, pp. 23,895-23,916, 1997. 
Tegen, I., S.P. Harrison, K. Kohfeld, C. Prentice, M. Heimann, The impact of vegetation and preferential source areas on global dust aerosols: Results from a model study, J. Geophys. Res, in press.

Torres, O., P. K. Bhartia, J.R. Herman, Z. Ahmad, and J. Gleason, Derivation of aerosol properties from a backscattered measurement of ultraviolet radiation : Theoretical basis, J. Geophys. Res, 108, 17,099-17,110, 1998.

Torres, O., Bhartia, P.K., Herman, J.R., Sinyuk, A., Ginoux, P., Holben, B, A Long-Term Record of Aerosol Optical Depth from TOMS observations and comparison to AERONET measurements. J. of the Atmospheric Sciences, 59(3), 398-413, 2002.

Woodward, S. ,Modeling the atmospheric life cycle and radiative impact of mineral dust in the Hadley Centre climate model, J. Geophys. Res., 106, pp. 18,155-18166 , 2001.

Zobler, L., A world file for global climate modelling. Technical Support, NASA-TM-87802, 1986. 